\title{
Penerapan Model Project Based Learning Berbantuan Media Pop Up Book Untuk Meningkatkan Kemampuan Berpikir Kreatif Siswa Kelas V
}

\author{
Novita Wulandari ${ }^{1)}$, Henny Dewi Koeswanti ${ }^{2}$, Sri Giarti ${ }^{3)}$ \\ 1) Universitas Kristen Satya Wacana,, Salatiga, Indonesia \\ E-mail:292015113@student.uksw.edu
}

\begin{abstract}
Abstrak. Penelitian yang dilakukan bertujuan untuk meningkatkan kemampuan berpikir kreatif siswa melalui penerapan model Project Based Learning. Jenis penelitian yang digunakan adalah Penelitian Tindakan Kelas (PTK). Subjek penelitian adalah siswa kelas V SD Negeri Banaran 5 yang berjumlah 12 siswa. Teknik yang digunakan dalam penelitian adalah dengan menggunakan empat tahap, yaitu perencanaan, pelaksanaan, observasi, dan refleksi. Hasil penelitian menunjukkan bahwa terdapat peningkatan, yang diupayakan melalui Project Based Learning antar siklus, yakni sebanyak (50\%) dari seluruh siswa mencapai kategori kemampuan berpikir kreatif cukup di pra siklus, meningkat menjadi (58,3\%) kategori berpikir kreatif tinggi di siklus I dan pada siklus II meningkat menjadi (91,7\%) kategori berpikir kreatif tinggi. Hasil ini menunjukan bahwa adanya peningkatan pada setiap kemampuan berpikir kreatif siswa dengan menerapkan model Project Based Learning, sehingga dapat disimpulkan bahwa model Project Based Learning dapat meningkatkan kemampuan berpikir kreatif.
\end{abstract}

Keywords: Project Based Learning; Kemampuan Berpikir Kreatif

\section{PENDAhUluan}

Pemberlakuan kurikulum 2013 merupakan inovasi yang dilakukan pemerintah pendidikan di Indonesia. Penelitian ini didukung oleh pendapat [5] yang menjelaskan bahwa kurikulum 2013 yang mengalami revisi dalam proses pembelajarannya harus mengintegrasikan beberapa aspek, diantaranya literasi, Penguatan Pendidikan Karakter (PPK), keterampilan abad 21 atau 4C (Creative, Critical Thinking, Communicative, Collaborative), dan HOTS (Higher Order Thinking Skills). Uraian diatas dapat diintegrasikan dengan cara merancangnya terlebih dahulu ke dalam bentuk Rencana Pelaksanaan Pembelajaran (RPP).

Tujuan kurikulum 2013 akan tercapai dengan baik bila dalam pelaksanaan dapat diterapkan dengan baik. Pada pembelajaran kurikulum 2013, guru lebih banyak berperan sebagai fasilitator karena dalam kurikulum terbaru guru lebih menempatkan siswa sebagai subyek belajar karena pada pembelajaran tematik berpusat pada siswa. Guru memiliki tugas untuk membimbing siswa agar dapat mencapai tujuan pembelajaran dan dapat mengelola kelas agar menjadi komunikatif dan kondusif selama proses pembelajaran berlangsung. Seorang guru diharapkan dapat dan mampu untuk mengelola pembelajaran dengan baik.

Guru berperan sebagai fasilitator yang dapat menciptakan kondisi yang lebih baik untuk siswa dalam setiap proses belajar mengajar [12]. Dengan demikian guru harus mampu menciptakan situasi yang menyenangkan di kelas sehingga dapat mendukung pelaksanaan kegiatan pembelajaran dengan baik serta mampu membimbing dan memotivasi siswa untuk lebih aktif. Dengan demikian guru harus mampu menciptakan situasi yang menyenangkan di kelas sehingga dapat mendukung pelaksanaan kegiatan pembelajaran dengan baik serta mampu membimbing dan memotivasi siswa untuk lebih aktif. Salah satu keterampilan yang dapat dikembangkan pada pembelajaran tematik adalah kemampuan berpikir kreatif.

Penerapan kurikulum 2013 menuntut guru menggunakan pendekatan dan model pembelajaran yang lebih inovatif dan kreatif. Model yang digunakan guru juga diharapkan mampu untuk menciptakan suasana kelas yang menyenangkan siswa dapat terlibat aktif dan dapat berkreasi dengan kreativitas ide yang dimiliki siswa dengan cara lebih menekankan pada suatu permasalahan sehingga siswa dapat memecahkannya. Berdasarkan observasi yang dilakukan di SD Negeri Banaran 5 pada pembelajaran tematik. Proses pembelajaran masih bersifat konvensional yang cenderung menggunakan model dan media yang kurang menarik dan masih menggunakan metode ceramah.

Pembelajaran secara konvensional cenderung membuat siswa mudah bosan dan kurang antusias dalam pembelajar, oleh sebab itu guru perlu melakukan inovasi dalam proses pembelajaran. Salah satu inovasi yang dapat dilakukan adalah dengan menggunakan model 
pembelajaran yang lebih inovatif. Model pembelajaran yang dapat menuntut siswa aktif dalam proses pembelajaran adalah model Project Based Learning. Menurut referensi [1] menyebutkan bahwa Project Based Learning merupakan salah satu model pembelajaran yang memiliki ciri khusus dengan merancang suatu kegiatan serta mampu menghasilkan suatu produk dari proyek yang dilakukan. Model pembelajaran ini memberikan pengalaman belajar secara langsung kepada siswa melalui kegiatan pembuatan proyek yang berujung pada terciptanya sebuah produk. Berdasarkan pendapat dapat disimpulkan bahwa Project Based Learning diharapkan siswa mampu mengembangkan suatu pengetahuan konsep dan keterampilan berpikir kreatif dengan bekerja secara kolaboratif dan dapat memberikan suatu solusi dalam menyelesaikan suatu permasalahan yang terjadi dengan menemukan hal-hal yang baru dan dapat menciptakan suatu idea atau produk.

Model Project Based Learning menurut referensi [10] yang menyebutkan bahwa langkah langkahnya terdiri dari : 1) Start With the Essential Question, pembelajaran dimulai dengan pertanyaan esensial, 2) Design a Plan for the Project, perencanaan dilakukan secara kolaboratif, 3) Create a Schedule, menyusun jadwal aktivitas, 4) Monitor the Students and the Progress of the Project, guru bertanggung jawab untuk melakukan monitor, 5) Assess the Outcom, membantu guru dalam mengukur ketercapaian standar, 6) Evaluate the Experience, guru dan siswa melakukan refleksi terhadap aktivitas dan hasil proyek yang sudah dilaksanakan.

Berdasarkan hasil observasi didapatkan pula bahwa kemampuan berpikir kreatif siswa masih kurang. Hal ini disebabkan karena dalam proses pembelajaran guru kurang mengajak siswa untuk terlibat langsung dalam melakukan kegiatan pengamatan. Kegiatan pengamatan dapat berguna untuk membuat siswa dapat menemukan masalah-masalah di sekitarnya, serta dapat menumbuhkan minat siswa untuk membuat produk yang berguna sebagai solusi pemecahan masalah. Kurangnya keterlibatan siswa dalam kegiatan pengamatan mengakibatkan tingkat berpikir kreatif siswa masih kurang dan akan berdampak juga pada hasil belajar siswa yang belum mencapai KKM. Hasil belajar merupakan hasil akhir dari proses pembelajaran yang disimbolkan dalam bentuk angka yang kegiatannya dilaksanakan di sekolahan [8].

Berdasarkan hasil observasi yang sudah dilakukan, maka dalam upaya meningkatkan kemampuan berpikir kreatif yang berpengaruh terhadap hasil belajar dilakukan inovasi dalam pembelajaran. Inovasi diharapkan dapat berdampak pada tingkat berpikir kreatif siswa. Kemampuan berpikir kreatif dapat diartikan sebagai kemampuan menciptakan sesuatu yang baru, atau kemampuan yang mampu untuk menempatkan dan mengombinasikan sejumlah objek secara berbeda yang berasal dari pemikiran manusia yang bersifat dapat dimengerti, berdaya guna, dan inovatif dengan berbagai macam faktor-faktor yang dapat mempengaruhi [6].
Selanjutnya berdasarkan referensi [9] menyebutkan bahwa kreativitas merupakan kemampuan siswa dalam menciptakan sesuatu hal yang baru dalam kegiatan belajarnya yang dapat berupa kemampuan mengembangkan sesuatu yang baru diperoleh dari guru dalam proses belajar mengajar sehingga dapat membuat hal yang baru dalam belajarnya. Berdasarkan pendapat dapat disimpulkan bahwa kemampuan berpikir kreatif adalah kemampuan yang dimiliki oleh setiap individu untuk dapat menciptakan dan menemukan sesuatu gagasan yang baru dengan cara pemikiran yang berbeda, ide dan model yang baru yang kemudian dikombonasikan menjadi hal yang inovatif dan dapat dimengerti.

Penanaman kebiasaan untuk berpikir secara kreatif perlu dibiasakan pada siswa melalui proses pembelajaran. Guru memegang peran dalam proses pembelajaran dan dapat berinteraksi secara langsung terhadap peserta didik. Guru diharapkan mampu menanamkan kebiasaan berpikir kreatif terhadap siswa. Ciri-ciri dari berpikir kreatif : 1) Kelancaran dalam berpikir merupakan kemampuan untuk mencetuskan banyak gagasan, jawaban dalam penyelesaian masalah atau pertanyaan, 2) Keluwesan dalam berpikir merupakan kemampuan untuk menghasilkan gagasan, jawaban atau pertanyaan yang bervariasi serta melihat suatu masalah dari sudut pandang yang berbeda-beda, 3) Keaslian adalah kemampuan untuk melahirkan gagasan-gagasan yang asli sebagai hasil pemikiran sendiri, memberikan jawaban yang lain dari yang lain, dan jarang diberikan kebanyakan orang, 4) Elaborasi adalah kemampuan untuk menambah, memperinci, dan memperluas sesuatu gagasan [4].

Penerapan model Project Based Learning dilakukan dengan berbantuan media pop up book. Menurut referensi [2] Media pembelajaran yang dapat digunakan sebagai sarana untuk menyalurkan pesan dan informasi materi pembelajaran sehingga dalam diri siswa terjadi proses belajar dalam rangka mencapai tujuan. Media Pop Up Book dapat memberikan kesan dalam dapat menarik perhatian siswa serta dapat menambah semangat belajar [11]. Dapat disimpulkan bahwa media Pop Up Book dapat menarik minat siswa untuk belajar karena dibuat dengan unsur gerak dan unsur 3 dimensi saat buku dibuka. Media Pop Up Book dapat memudahkan siswa untuk memahami materi yang disampaikan oleh guru dan dapat menangkap apa yang dijelaskan oleh guru siswa juga dapat aktif dan semangat membuat kreasi.

Dengan model pembelajaran yang inovatif dan kreatif, diharapkan siswa menjadi aktif, kreatif, dan senang terhadap pembelajaran sehingga tujuan pembelajaran dapat terlaksana dengan baik. Perumusan masalah pada penelitian ini yaitu "Apakah penerapan model pembelajaran Project Based Learning berbantuan media pop up book dapat meningkatkan kemampuan berpikir kreatif siswa pada pembelajaran Tematik SD Kelas V ?’. Salah satu model pembelajaran yang mampu mengatasinya adalah dengan menerapkan model Project Based Learning dengan berbantuan media Pop Up Book yang dapat dijadikan alternatif untuk diterapkan yang bermanfaat 
untuk siswa dalam meningkatkan kemampuan berpikir kreatif dan berpengaruh pada hasil belajar siswa kelas V SD Negeri Banaran 5 Tahun Pelajaran 2018/2019.

\section{METODE PENELITIAN}

Penelitian ini menggunakan jenis Penelitian Tindakan Kelas (PTK), yang dilakukan selama dua siklus dimana tiap siklusnya terdiri dari 3 pertemuan hingga indikator dapat tercapai untuk meningkatkan kemampuan berpikir kreatif siswa dan hasil belajar pada pembelajaran tematik siswa kelas V SD dengan menerapkan model pembelajaran Project Based Learning berbantuan Pop Up Book. Penelitian Tindakan Kelas (PTK) merupakan salah satu upaya yang dilakukan guru untuk meningkatkan kualitas peran dan tanggung jawab guru khususnya dalam pengelolaan pembelajaran [7].

PTK dilakukan secara kolaboratif dalam artian peneliti dapat berkolaborasi dengan guru kelas dalam melakukan PTK. Penelitian dilaksanakan di SD Negeri Banaran 5 pada bulan Februari 2019 adapun untuk subjek penelitian adalah siswa kelas $\mathrm{V}$ yang berjumlah 12 siswa. Teknik yang digunakan dalam penelitian adalah dengan menggunakan empat tahap, yaitu perencanaan, pelaksanaan, observasi, dan refleksi.

\section{HASIL DAN PEMBAHASAN}

Hasil penelitian yang sudah dilakukan menggunakan model Project Based Learning menunjukan adanya peningkatan pada kemampuan berpikir kreatif dan hasil belajar siswa kelas V SD Negeri Banaran 5, berikut hasil penelitian pada kemampuan berpikir kreatif siklus I :

Tabel 1.

Tingkat Kemampuan Berpikir Kreatif Siswa Kelas V SD Negeri Banaran 5 Siklus I

\begin{tabular}{ccccc}
\hline $\begin{array}{c}\text { Penguasaan } \\
\text { Materi }\end{array}$ & $\begin{array}{c}\text { Rentan } \\
\text { g Skor }\end{array}$ & Ket & $\begin{array}{c}\text { Frek } \\
\text { uensi }\end{array}$ & $\begin{array}{c}\text { Persen } \\
\text { tase \% }\end{array}$ \\
\hline $85-100$ & $3-4$ & $\begin{array}{c}\text { Berpikir } \\
\text { kreatif tinggi }\end{array}$ & 7 & $58,3 \%$ \\
\hline $70-84$ & $2-2,9$ & $\begin{array}{c}\text { Berpikir } \\
\text { kreatif cukup }\end{array}$ & 4 & $33,3 \%$ \\
\hline$<69$ & $<1,9$ & $\begin{array}{c}\text { Berpikir } \\
\text { kreatif rendah }\end{array}$ & 1 & $8,3 \%$ \\
\hline & Jumlah & 12 & $100 \%$ \\
\hline
\end{tabular}

Berdasarkan tabel 1 di atas dapat diketahui bahwa kemampuan berpikir kreatif siswa yang rendah. pada kategori berpikir kreatif tinggi terdapat 7 siswa dengan persentase $(58,3 \%)$, pada kategori berpikir kreatif cukup terdapat 4 siswa dengan persentase sebesar $(33,3 \%)$, dalam kategori berpikir kreatif rendah terdapat 1 siswa dengan persentase sebesar $(8,3 \%)$.

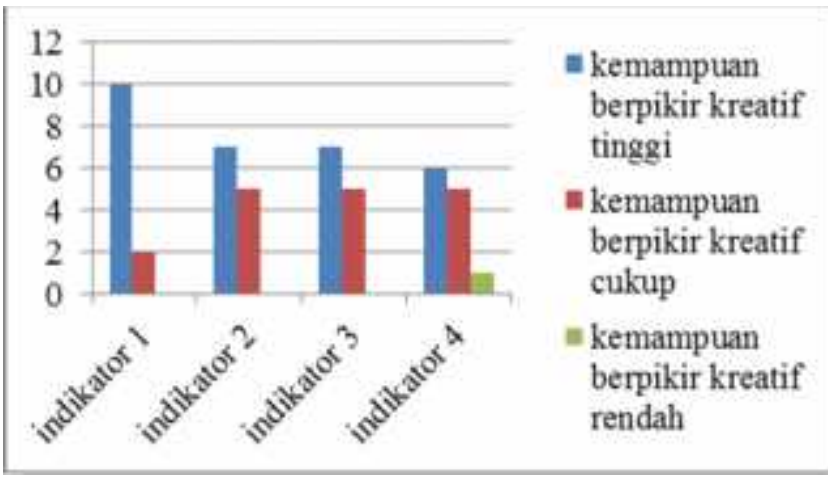

Gambar 1. Diagram Tingkat Kemampuan Berpikir Kreatif Siswa Kelas V SD Negeri Banaran 5 Siklus I

Tabel 2.

Tingkat Kemampuan Berpikir Kreatif Siswa Kelas V SD Negeri Banaran 5 Siklus II

\begin{tabular}{ccccc}
\hline $\begin{array}{c}\text { Penguasaan } \\
\text { Materi }\end{array}$ & $\begin{array}{c}\text { Rentang } \\
\text { Skor }\end{array}$ & Ket & $\begin{array}{c}\text { Freku } \\
\text { ensi }\end{array}$ & $\begin{array}{c}\text { Persen } \\
\text { tase \% }\end{array}$ \\
\hline $85-100$ & $3-4$ & $\begin{array}{c}\text { Berpikir } \\
\text { kreatif tinggi }\end{array}$ & 11 & $91,7 \%$ \\
\hline $70-84$ & $2-2,9$ & $\begin{array}{c}\text { Berpikir } \\
\text { kreatif cukup }\end{array}$ & 1 & $8,3 \%$ \\
\hline$<69$ & $<1,9$ & $\begin{array}{c}\text { Berpikir } \\
\text { kreatif } \\
\text { rendah }\end{array}$ & 0 & $0 \%$ \\
\hline & Jumlah & 12 & $100 \%$ \\
\hline
\end{tabular}

Berdasarkan tabel 2 di atas dapat diketahui bahwa kemampuan berpikir kreatif siswa yang rendah. pada kategori berpikir kreatif tinggi terdapat 11 siswa dengan persentase $(91,7 \%)$, pada kategori berpikir kreatif cukup terdapat 1 siswa dengan persentase sebesar $(8,3 \%)$, dalam kategori berpikir kreatif rendah terdapat 0 siswa dengan persentase sebesar (0\%).

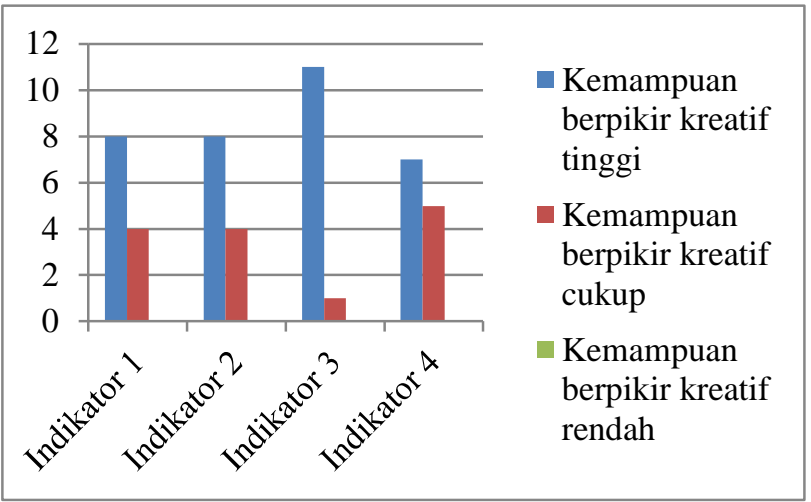

Gambar 2. Diagram Tingkat Kemampuan Berpikir Kreatif Siswa Kelas V SD Negeri Banaran 5 Siklus II 
Perbandingan hasil penelitian kemampuan berpikir kreatif siswa dari pelaksanaan pra siklus, siklus I, dan siklus II dapat dilihat pada tabel dan diagram berikut ini :

Tabel 3.

Distribusi Frekuensi Kemampuan Berpikir Kreatif Berdasarkan Klasifikasi Pra Siklus, Siklus 1 dan Siklus II

\begin{tabular}{rlccc}
\hline \multicolumn{1}{c}{ No } & Kategori & Pra Siklus & Siklus I & Siklus II \\
\hline 1. & Berpikir Kreatif Tinggi & $0 \%$ & $58,3 \%$ & $91,7 \%$ \\
\hline 2. & Berpikir Kreatif Cukup & $50 \%$ & 33,3 & $8,3 \%$ \\
\hline 3. & Berpikir Kreatif Rendah & $50 \%$ & $8,3 \%$ & $0 \%$ \\
\hline & Jumlah & $100 \%$ & $100 \%$ & $100 \% \%$ \\
\hline
\end{tabular}

Tabel 3 di atas menunjukan perbandingan kemampuan berpikir kreatif SD Negeri Banaran 5 meningkat, hal ini diapat dilihat dari kategori kemampuan berpikir kreatif tinggi pada pra siklus sebesar $(0 \%)$, pada kategori kemampuan berpikir kreatif cukup sebesar (50\%), dan kategori kemampuan berpikir kreatif rendah sebesar $(50 \%)$. Pada siklus I kategori kemampuan berpikir kreatif tinggi sebesar (58,3\%), pada kategori kemampuan berpikir kreatif cukup sebesar $(33,3 \%)$, dan pada kategori kemampuan berpikir kreatif rendah sebesar $(8,3 \%)$. Pada tahap siklus II kemampuan berpikir kreatif tinggi sebesar $(91,7 \%)$, pada kategori kemampuan berpikir kreatif cukup sebesar $(8,3 \%)$, sedangkan pada kategori kemampuan berpikir rendah $(0 \%)$. Hal ini menunjukan pada setiap siklusnya terdapat adanya peningkatan.

Tabel 4.

Perbandingan Hasil Belajar Pra Siklus, Siklus I, dan Siklus II Siswa Kelas V SD Negeri Banaran 5

\begin{tabular}{cccccccc}
\hline No. & Nilai & \multicolumn{2}{c}{ Pra Siklus } & \multicolumn{2}{c}{ Siklus I } & \multicolumn{2}{c}{ Siklus II } \\
\cline { 2 - 8 } & F & $\begin{array}{c}\text { Persen } \\
\text { \% }\end{array}$ & F & $\begin{array}{c}\text { Persen } \\
\text { \% }\end{array}$ & F & $\begin{array}{c}\text { Persen } \\
\%\end{array}$ \\
\hline 1. & Tuntas & 5 & $41.7 \%$ & 8 & $66,7 \%$ & 11 & $91,7 \%$ \\
\hline 2. & $\begin{array}{c}\text { Belum } \\
\text { Tuntas }\end{array}$ & 7 & $58,3 \%$ & 4 & $33,3 \%$ & 1 & $8,3 \%$ \\
\hline & Jumlah & 12 & $100 \%$ & 12 & $100 \%$ & 12 & $100 \%$ \\
\hline
\end{tabular}

Berdasarkan Tabel 4. bahwa siswa yang mengalami ketuntasan belajar pra siklus sebanyak 5 siswa $(41,7 \%)$. Setelah menerapkan model pembelajaran Project Based Learning dalam pelaksanaan proses pembelajaran maka terjadi peningkatan dari pra siklus ke siklus I menjadi 8 siswa $(66,7 \%)$ dan ada peningkatan pula dari siklus I ke siklus II menjadi 11 siswa $(91,7 \%)$. Dalam hal ini pada pra siklus yang belum tuntas mencapai 7 siswa, pada siklus I menurun menjadi 4 siswa. Selanjutnya dari siklus I ke siklus II, siswa yang belum mencapai KKM terbukti terjadi penurunan yaitu menjadi 1 siswa.

Berdasarkan hasil penelitian yang telah dilaksanakan pada kelas V di SD Negeri Banaran 5 Sragen semester II tahun ajaran 2018/2019 diketahui peningkatan kemampuan berpikir kreatif dan hasil belajar siswa pada kegiatan pembelajaran siklus I dan siklus II dalam penerapan model Project Based Learning. Hal ini dapat diketahui adanya peningkatan kemampuan berpikir kreatif dari pra siklus sampai siklus II. Peningkatan kemampuan berpikir kreatif dan hasil belajar pembelajaran tematik siswa kelas $\mathrm{V}$ dengan menerapkan model pembelajaran Project Based Learning dapat dibuktikan dalam penelitian ini. Hasil penelitian menunjukkan bahwa terdapat peningkatan, yang diupayakan melalui Project Based Learning antar siklus, yakni sebanyak $50 \%$ kategori (berpikir kreatif cukup) dari seluruh siswa mencapai kemampuan berpikir kreatif cukup di pra siklus, meningkat menjadi 58,3\% kategori (berpikir kreatif tinggi) di siklus I dan pada siklus II meningkat menjadi 91,7\% kategori (berpikir kreatif tinggi).

Kemampuan berpikir kreatif dalam pembelajaran tematik meliputi aspek membuat 6 pertanyaan tentang keragaman budaya yang menggunakan aspek apa, di mana, kapan, siapa, mengapa, dan bagaimana, merumuskan dan mengemukakan 4 faktor penting penyebab penjajahan bangsa Indonesia dan upaya bangsa Indonesia dalam mempertahankan kedaulatannya, mampu mengajukan 4 jawaban sikap untuk menyikapi keberagaman sosial budaya yang di dapatkan dan mampu menambahkan 4 gagasan kegiatan yang mendukung keberagaman sosial budaya masyarakat. Tindakan penelitian ini dilaksanakan dengan berkolaborasi guru kelas V, pada tindakan dilaksanakan dalam dua siklus dan setiap siklusnya terdiri dari enam pertemuan. Pembelajaran Project Based Learning diharapkan mampu memberikan solusi penyelesaian masalah yang terjadi dengan menciptakan suatu ide atau menciptakan produk dengan memanfaatkan lingkungan sekitar [3].

Kemudian hasil belajar siswa dilihat pada pra siklus sebanyak 5 siswa $(41,7 \%)$ tuntas dan sebanyak 7 siswa $(58,3 \%)$ tidak tuntas, meningkat pada siklus I hasil belajar siswa sebanyak 8 siswa $(66,7 \%)$ tuntas dan sebanyak 4 siswa $(33,3 \%)$ tidak tuntas. Selanjutnya pada siklus II hasil belajar meningkat sebanyak 11 siswa $(91,7 \%)$ tuntas dan sebanyak 1 siswa $(8,3 \%)$ tidak tuntas.

Berdasarkan penelitian yang dilakukan dalam dua siklus, dapat disimpulkan bahwa model pembelajaran Project Based Learning yang diterapkan pada siswa kelas V SD Negeri Banaran 5 tahun ajaran 2018/2019 dapat meningkatkan kemampuan berpikir kreatif dan hasil belajar pada pembelajaran tematik.

\section{KESIMPULAN DAN SARAN}

\section{Kesimpulan}

Berdasarkan hasil penelitian dan pembahasan maka diperoleh kesimpulan, sebagai berikut :

1. Penerapan model pembelajaran Project Based Learning berhasil meningkatkan kemampuan berpikir kreatif dan hasil belajar.

2. Dapat meningkatkan kemampuan berpikir kreatif siswa kelas V SD Negeri Banaran 5 yang ditandai dengan kenaikan nilai kemampuan berpikir kreatif yang diupayakan melalui Project Based Learning antar siklus, yakni sebanyak 50\% (berpikir kreatif cukup) dari seluruh siswa mencapai kemampuan berpikir kreatif cukup di pra siklus, meningkat menjadi 58,3\% (berpikir kreatif tinggi) di siklus I dan pada siklus II meningkat menjadi 91,7\% (berpikir kreatif tinggi).

3. Berpengaruh pada hasil belajar siswa kelas V SD Negeri Banaran 5 yang ditandai dengan kenaikan nilai hasil belajar yang terdiri dari pra siklus dengan persentase $(41,7 \%)$ kemudian meningkat pada siklus I dengan 
persentase $(66,7 \%)$ dan menjadi meningkat pada siklus II dengan persentase $(91,7 \%)$ menjadikan hasil belajar siswa meningkat.

\section{Saran}

Berdasarkan kesimpulan dan implikasi hasil penelitian, maka saran yang dapat diajukan adalah :

1. Bagi Siswa, seharusnya dalam kegiatan berdiskusi siswa dapat berpartisipasi aktif, siswa diharapkan juga lebih memperhatikan dan mendengarkan guru serta teman yang sedang berpresentasi di depan kelas. Siswa dalam membuat suatu proyek dapat berperan aktif pada saat pembelajaran berlangsung sehingga dapat menjadi bermakna dan proyek yang dikerjakan terlaksana dengan baik.

2. Sebagai guru perlu mengerti dan paham cara mengelola kelas. Guru membimbing siswa agar siswa dapat terlibat aktif didalam pengerjaan proyek siswa,

3. Sekolah dapat menggunakan model pembelajaran Project Based Learning yang dapat diterapkan dalam setiap pembelajaran di sekolah.

4. Bagi peneliti selanjutnya dengan hasil penelitian ini diharapkan dapat dijadikan sebagai bahan referensi bagi penelitian yang sama dan penelitian yang selanjutnya dapat lebih baik dari penelitian yang sebelumnya.

\section{DAFTAR PUSTAKA}

[1] Ardianti, S. D., Pratiwi, I. ari, \& Kanzunnudin., M. (2017) Implementasi Project Based Learning (PjBL) Berpendekatan, 7(2), 145-150.

[2] Mawardi. (2018). Merancang Model dan Media Pembelajaran Jurnal Pendidikan Dan Kebudayaan, 8, 26-40. https://doi.org/https://doi.org/10.24246/j.js.2018.v8.i1.p26-40

[3] Maula, M. M., Prihatin, J., Fikri, K., Mipa, J. P., Keguruan, F., \& Unej, U. J. (2014). Pengaruh Model PjBL ( Project-Based Learning ) terhadap Kemampuan Berpikir Kreatif dan Hasil Belajar Siswa pada Materi Pengelolaan Lingkungan ( The Effect of PjBL ( Project-Based Learning ) Model of Creative Thinking Ability and Learning Achievement in Ma. Research Education, 1$6 . \quad$ Retrieved from http://repository.unej.ac.id/handle/123456789/63447

[4] Munandar, S. C. U. (1999). Kreativitas dan keberbakatan: Strateg mewujudkan potensi kreatif dan bakat. Gramedia Pustaka Utama.

[5] Rafianti, I., Setiani, Y., \& Novaliyosi, N. (2018). Profi Kemampuan Literasi Kuantitatif Calon Guru Matematika. Jurnal Penelitian Dan Pembelajaran Matematika, 11(1). https://doi.org/10.30870/jppm.v11i1.2985

[6] Mursidik, E. M., Samsiyah, N., \& Rudyanto, H. E. (2016) Kemampuan Berpikir Kreatif Dalam Memecahkan Masalah Matetatika Open-Ended Ditinjau Dari Tingkat Kemampuan Matematika Siswa Sekolah Dasar. PEDAGOGIA: Jurnal Pendidikan, 4(1), 23. https://doi.org/10.21070/pedagogia.v4i1.69

[7] Sanjaya, D. H. W. (2016). Penelitian tindakan kelas. Prenada Media.

[8] Setiaji. (2018). Perbedaa Penggunaan Discovery Learning Dan Problem Solving Terhadap Hasil Belajar IPA Siswa Kelas 4. Jurnal Basicedu, 2(Model discovery learning dan model problem solving), 11-18.

[9] Titu, M. A. (2015). Penerapan Model Pembelajaran Berbasis Proyek untuk Meningkatkan Kreatifitas Siswa pada Materi Konsep Masalah Ekonomi. Prosiding Seminar Nasional, 176-186. https://doi.org/10.1017/S0025315409000708

[10] Wahyu, R. (2013). Implementasi Model Project Based Learning PJBL ) Ditinjau dari Penerapan Kurikulum 2013, (2009).

[11] Wati, E. T., \& Zudhi, U. (2017). PENGARUH MEDIA POP-UP BOOK TERHADAP HASIL BELAJAR SISWA TEMA
EKOSISTEM KELAS V SDN KARANGPALANG 1 SURABAYA. Jurnal Penelitian Pendidikan Guru Sekolah Dasar $5(3)$

[12] Yufita Ina Azariya, T. W. (2013). Penerapan model pembelajaran. Jurnal PGSD Universitas Surabaya, 01 Nomor 0, 0-216. 